\title{
ETIKA PROFESI DALAM PROBLEMATIKA DI ERA COMPETITIF MENURUT SISI PANDANG AKUNTAN PUBLIK
}

\author{
Koenta Adji Koerniawan
}

\begin{abstract}
Etika Profesi menjadi isyu penting dalam kurun waktu 10 tahun terakhir, terutama yang berkaitan dengan praktek di dunia Kantor Akuntan Publik. Diskusi-diskusi tentang Etika Profesi dalam berbagai pembahasan lebih banyak diarahkan pada aktivitas praktisi Akuntan Publik, meski secara makna Etika Profesi sesungguhnya tidak hanya menjadi domain bagi Akuntan Publik yang berpraktek di Kantor Akuntan Publik, namun secara luas hal tersebut menjadi prinsip etik bagi setiap akuntan atau setidaknya mereka yang menerjuni beragam profesi dengan basis ilmu akuntansi sebagai bidang aktifitas yang digelutinya. Karenanya, Etika Profesi sesungguhnya juga berlaku bagi para akuntan yang berprofesi sebagai Auditor Pemerintah, Akuntan Intern, Auditor Intern, Konsultan Pajak, bahkan Dosen. Hal ini mengandung konsekuensi adanya Etika Profesi Akuntan Pemerintahan, Etika Profesi Akuntan Internal, Etika Profesi Akuntan Konsulen Pajak, atau Etika Profesi Akuntan Pendidik. Namun dalam perkembangannya hingga saat ini aktifitas di Kantor Akuntan Publik yang lebih banyak dijadikan sorotan dan obyek-obyek dalam aktifitas kegiatan penelitian. Seolah Etika Profesi Akuntan, hanya diperuntukkan bagi Akuntan yang berpraktek di Kantor Akuntan Publik. Tidak dipungkiri, beragam kasuskasus besar memang terjadi di dunia Kantor Akuntan Publik, namun hingga saat ini belum ada penelitian yang mencoba melakukan telaah penelitian terhadap komparasi intensitas frekwensi terjadinya pelanggaran Etika Profesi Akuntan, untuk beragam Profesi yang digeluti Akuntan. Dalam pandangan Akuntan Publik, Etika Profesi menjadi fokus perhatian mereka adalah Etika Profesi Akuntan Publik, yang di release oleh IAPI. Ia menjadi tahap awal sebelum Akuntan Publik melaksanakan sebuah perikatan dengan klien. Paper ini akan mencoba mendiskusikan tentang makna Etika dalam model moral kognitif, serta dalam pandangan Syariah Islam. Kemudian pembahasan dirangkai dengan garis besar prinsip-prinsip Etika Profesi yang dipergunakan AICPA, AAOIFI. Perspektif Akuntan Publik di Indonesia terhadap Etika Profesinya akan diketengahkan untuk melengkapi bahasan.
\end{abstract}

Keywords: Moral, Kognitif, Syariah, IAPI, AAOIFI, Perspektif Akuntan Publik.

Koenta Adji Koerniawan, Dosen Prodi Akuntansi Universitas Kanjuruhan Malang 


\section{PENDAHULUAN}

Etika Profesi Akuntan menjadi kajian dan isue krusial saat beberapa kasus besar melanda dunia Kantor Akuntan Publik. Publik memperoleh informasi tentang kejadian di USA yang dipicu oleh skandal Enron, Worldcom dan beberapa perusahaan besar di USA di sekitar tahun 2002. Kejadian tersebut menjadi penyebab ditutupnya Enron juga Kantor Akuntan Publik terbesar di dunia saat itu, Andersen. Sementara beberapa kejadian di dalam negeri yang melanda Kantor Akuntan Publik juga terjadi. Kasus PT Telkom, PT Kereta Api Indonesia, PT Kimia Farma adalah beberapa contoh. Beberapa kalangan ahli berpendapat kasuskasus tersebut terjadi karena terjadinya kegagalan di dalam menerapkan Etika Profesi Akuntan dalam praktek Akuntan Publik. Meski sesungguhnya prinsipprinsip Etika Profesi Akuntan tidak hanya berlaku untuk profesi Akuntan Publik, namun mengikat juga bagi profesi-profesi lain yang menggeluti bidang keahlian akuntansi. Karenanya, profesi Auditor Pemerintah, Akuntan Internal, Auditor Internal hingga Dosen, sesungguhnya juga terikat dengan Etika Profesi Akuntan. Masyarakat terlanjur memahami bahwa Etika Profesi Akuntan = Etika Profesi Akuntan Publik. Padahal faktanya apabila merujuk pada pembidangan profesi yang ada di dalam IAI (Ikatan Akuntan Indonesia), maka setidaknya akan terdapat (1) Kompartemen Akuntan Sektor Publik (2) Kompartemen Akuntan Manajemen (3) Kompartemen Akuntan Pendidik. Sementara untuk Akuntan Publik, telah lepas dari IAI dan mendirikan wadah IAPI organisasi (Institut Akuntan Publik Indonesia). Akuntan yang berprofesi sebagai Konsulen Pajak, tergabung di dalam wadah organisasi IKPI (Ikatan Konsulen Pajak Indonesia). Dengan demikian menyamakan terminologi Etika Profesi Akuntan dengan Etika Profesi Akuntan Publik, adalah kurang tepat. Mungkin karena dampak yang ditimbulkan oleh pelanggaran Etika lebih langsung dirasakan masyarakat ekonomi (berkurangnya kepercayaan investor yang ditampakkan dengan berkurangnya transaksi yang terjadi di Pasar Modal), serta ada Blow up media secara besar-besaran maka seolah masalah Etika Profesi Akuntan hanya menjadi domain bagi Kantor Akuntan Publik dan Akuntan Publik.

Sebagai sebuah contoh, kasus yang terjadi di PT KAI (misalnya) tidak murni kesalahan dari KAP dan AP yang melakukan audit pada periode ditemukannya kesalahan. Karena sebelumnya audit di PT KAI dilakukan oleh auditor Pemerintah sebelum digantikan posisinya oleh KAP. Akumulasi kesalahan terjadi bertahun-tahun pada saat auditor Pemerintah melakukan audit. Saat digantikan oleh KAP kesalahan tersebut terdeteksi. Kesalahan fatal yang dilakukan oleh KAP dan AP yang menggantikan posisi Auditor Pemerintah saat itu adalah, tidak meminta Auditor terdahulu (Auditor Pemerintah) untuk mengkoreksi laporan auditannya, dan menerbitkan kembali Laporan Auditannya. Akibatnya, KAP dan AP pengganti, dibebani kesalahan. Contoh lain, Akuntan yang berprofesi sebagai pengajar (dosen) menurut ketentuan akademik dan berdasarkan pada standar Beban Kinerja Dosen (BKD) diwajibkan untuk melaksanakan kegiatan pengajaran selama 14 kali pertemuan ditambah dengan 1 kali UTS dan 1 kali UAS, sehingga total kegiatan pembelajaran adalah sebanyak 16 kali dalam 1 semester. Karena alasan kesibukan atau alasan yang lain, banyak Akuntan yang berprofesi sebagai Dosen, tidak dapat memenuhi kontrak perkuliahan tersebut. Hal ini juga merupakan salah satu contoh dari sebuah pelanggaran Etika Profesi Akuntan. Belum lagi jika hal 
tersebut dicoba untuk dihubungkan dengan kompetensi Dosen, maka akan terlihat begitu banyak Akuntan yang berprofesi sebagai Dosen, tidak memahami perkembangan terkini dari Ilmu Akuntansi. Akibatnya, materi bahan ajar yang diajarkan kepada mahasiswa, menjadi out of dated, sudah tidak sesuai dengan situasi dan kondisi jaman. Sayangnya, hingga saat ini penelitian tentang Etika Profesi Akuntan yang mengamati profesi lain selain dari profesi Akuntan Publik, masih sangat jarang dilakukan.

Aktifitas riset dari kalangan akademisi didominasi oleh topik-topik penelitian Etika Profesi Akuntan dengan mengambil obyek Akuntan Publik dan Kantor Akuntan Publik. Sebagai contoh penelitian tentang Etika Akuntan, adalah seperti yang dilakukan oleh Volker (1984), Bebeau, et al (1985) menyatakan bahwa para Akuntan Profesional cenderung mengabaikan persoalan moral bilamana menemukan masalah yang bersifat teknis. Kemudian, Cushing (1999) yang menawarkan sebuah kerangka kerja berdasarkan Game Theory untuk melakukan pengujian pendekatan standar Etika dengan profesi Akuntan (baca: Akuntan Publik). Penelitian yang dilakukan oleh Ludigdo (1999) menghasilkan rumusan bahwa pelanggaran Etika seharusnya tidak terjadi apabila Akuntan memiliki pengetahuan, pemahaman, serta kemauan dalam menerapkan nilai-nilai moral dan etika secara memadai dalam pelaksanaan pekerjaan profesionalnya. Hasil Penelitian Payamta (2002) menyatakan bahwa berdasarkan Pedoman Etika IFAC, maka syarat-syarat etika suatu organisasi akuntan, sebaiknya didasarkan pada prinsip-prinsip dasar yang mengatur tindakan/ perilaku seseorang akuntan dalam melaksanakan tugas profesionalnya. Prinsip-prinsip tersebut meliputi: (1) Integritas, (2) Obyektifitas, (3) Independensi, (4) Kepercayaan, (5) Standar-standar teknis, (6) Kemampuan Profesional, dan (7) Perilaku Etika. Yang menarik adalah pendapat dari Sudibyo (1995) dalam Khomsiyah dan Indriantoro (1998) yang menyatakan bahwa Dunia Pendidikan Akuntansi memiliki pengaruh yang besar terhadap perilaku Etika dari Auditor. Pendapat dari Sudibyo seolah memberikan informasi bagi kita, bahwa ketika kita berbicara Etika Profesi Akuntan Publik maka hal tersebut juga memiliki kaitan dengan implementasi Etika Profesi Akuntan Pendidik. Karenanya gambaran umum tentang Etika Profesi Akuntan dan pengelompokkannya, serta sumber referensinya digambarkan dalam Gambar 1 berikut: 


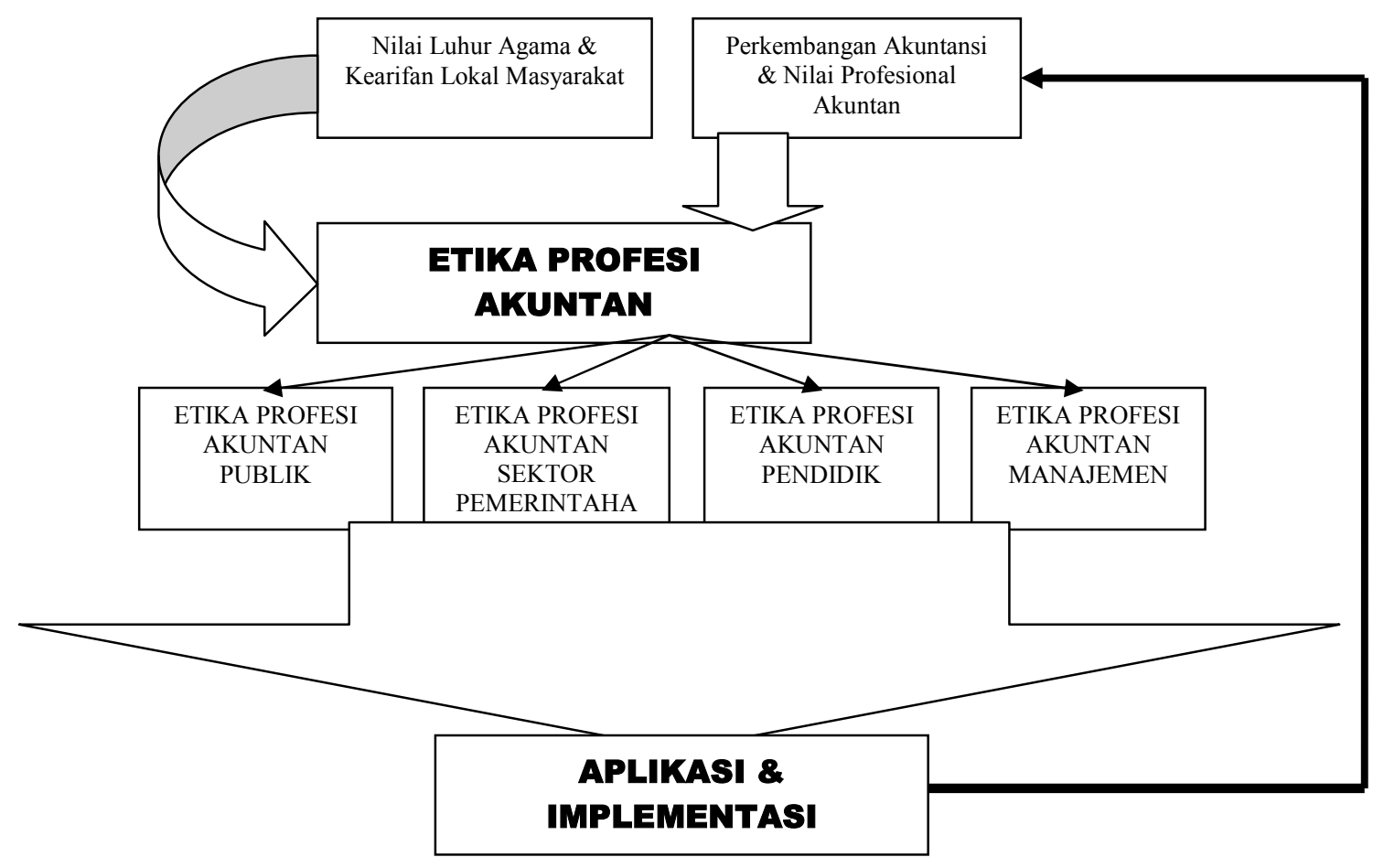

Gambar 1. Etika Profesi Akuntan dan Pengelompokannya

\section{ETIKA, MORAL, KOGNITIF}

Dari pandangan Etimologi, Etika berasal dari bahasa Yunani "ethos" (bentuk tunggal) yang berarti adat, kebiasaan, watak, perasaan, sikap, cara berpikir. Dalam bentuk jamak (ta etha) yang berarti adat kebiasaan. Filosof Yunani terkenal Aristoteles (384-322 SM) telah menggunakan istilah ethos untuk menjelaskan filsafat moral. Dalam kamus umum Bahasa Indonesia, Etika adalah ilmu pengetahunan tentang azaz-azaz moral. Sementara dalam kamus Echol dan Shadaly (1995) Etika adalah perilaku etis, layak, beradab, dan bertata susila. Dari pandangan normatif, Etika adalah serangkaian prinsip-prinsip moral yang memisahkan hal yang baik dan hal yang buruk serta apa yang harus dilakukan dan tidak harus dilakukan oleh seseorang (Stead et al, 1990). Sementara menurut Satyagraha (2003:4) Etika adalah nilai-nilai dan norma-norma moral dalam suatu masyarakat. Karenanya Etika diartikan sebagai moralitas. Hal tersebut sejalan dengan pendapat Boynton dan Kell (1996) yang mendefinisikan etika sebagai sebuah pranata yang terdiri dari prinsip-prinsip moral dan standar yang berfokus pada perilaku manusiawi untuk dapat menentukan "benar" dan "salah". Demikian juga dengan Arens-Loebbecke (1996) berpendapat bahwa Etika berkaitan dengan perangkat moral dan nilai. Karenanya, Etika merupakan suatu prinsip moral dan perilaku yang menjadi dasar bertindak bagi seseorang, sehingga apa yang dilakukannya dinilai sebagai sebuah perbuatan yang terpuji sehingga meningkatkan derajat martabat serta kehormatan bagi seseorang (Munawir, 1997). 
Moral diartikan sebagai nilai-nilai serta norma-norma yang menjadi dasar pegangan bagi seseorang atau sekolompok orang dalam bertindak. Kata Moral berasal dari bahasa latin "Mos" yang memiliki arti: Kebiasaan. Morris berarti kebiasaan moral. Dalam teori Philosophia Moralis, terdapat 4 gaya pemikiran dari perkembangan moral, yaitu Deontological, Teleological, Conventional, Egois (Fraedrich \& Ferrell 1992a, 1992b; Harris \& Sutton,1995; Reidenbach \& Robin,1990). Deontological merupakan perkembangan moral yang berfokus pada maksud untuk mewujudkan tujuan-tujuan yang penting, ideal dengan nilai-nilai umum. Pada pendekatan ini, fokus perhatian tidak hanya pada perilaku dan tindakan, namun juga pada bagaimana seseorang dapat mencapai tujuan dengan berdasarkan pada nilai-nilai kebenaran hakiki. Pendekatan Teleological menekankan pada maksimalisasi kebaikan melalui perilaku dan tindakan agar memberi manfaat kepada sekelompok orang atau sebanyak-banyaknya orang. Pemikiran Conventional mengacu pada tindakan yang harus bersesuaian dengan Hukum, Norma dan Kode Etik Profesional. Sementara untuk pendekatan pemikiran Egois berfokus pada tindakan kebaikan untuk kepentingan diri sendiri. Karenanya hirarki tentang pemikiran Moral akan menghasilkan pengembangan Teori Etika dari mulai Egois, Conventional, Teleological, hingga Deontological.

Cognitive memiliki arti pengertian, mengerti. Dalam makna yang luas Cognition berarti perolehan, penataan dan penggunaan pengetahuan (Nelsser, 1976). Kognitif menjadi istilah yang begitu populer di ilmu Psikologis yang mencakup segala aspek pengenalan terhadap perilaku mental yang berhubungan dengan pemahaman manusia terhadap lingkungannya berdasarkan Konasi (Kehendak) dan Efeksi (Perasaan). Kalangan ahli jiwa berpendapat, tingkah laku manusia akan senantiasa didasarkan pada Kognisi, yaitu tindakan untuk mengenali dan memikirkan situasi dimana tingkah laku itu terjadi.

Pada tahun 1960-1970, Kohlberg berdasarkan penelitian empirisnya menghasilkan teori Kognitif development. Dalam teori tersebut disebutkan bahwa pada intinya moralitas mewakili seperangkat pertimbangan dan keputusan rasional yang berlaku dalam setiap kebudayaan, melalui prinsip kesejahteraan dan keadilan. Teori pemikiran Lawrence Kohlberg ini menghasilkan 3 tingkat tahap perkembangan moral manusia, yaitu:

1. Tahap Pra Konvensional, pada tahap ini manusia mengenali awal konsep moral yang ditafsirkan secara fisis dan hedonistis. Jika jahat dihukum jika baik diberi hadiah. Tindakan yang baik akan mendapat pujian dan hadiah, dan karenanya berakibat baik secara fisik pada diri sendiri. Dalam tahap ini terdiri dari 2 tahapan yaitu: (1) Punishment and obedience Orientation. (2) Instrument Relativist Orientation.

2. Tahap Konvensional, pada tahap ini manusia mulai belajar tentang kemasyarakatan. Mereka belajar secara aktif menunjang ketertiban dan berusaha untuk mempu mengidentifikasi diri mereka dalam sebuah ketertiban sosial. Dalam tahap ini terdiri dari 2 tahapan yaitu: (1) Interpersonal Concordance (Good boy-nice girl). (2) Law and order orientation.

3. Tahap Setelah Konvensional, pada tahap ini manusia mulai mencari prinsip-prinsip moral berdasarkan pada nilai-nilai yang valid dan yang dapat diimplementasikan. Prinsip tersebut dapat bersumber pada otoritas 
sekelompok orang atau melalui sumber-sumber yang lain. Dalam tahapan ini terdiri dari 2 tahapan: (1) Social Contract Orientation. (2) The Universal Ethical Principle Orientation.

Teori dari Lawrence Kohlberg ini dihasilkan melalui 14 tahun penelitiannya dan dipengaruhi oleh pemikiran moral dari John Dewey, Baldwin, Jean Pieget serta Emile Durkheim. Menurut Bertens Teori Kohlberg ini menjadi pilar penting yang mempengaruhi dunia Psikologi dan Filsafat Moral atau Etika (Bertens, 2000).

\section{ETIKA DALAM PERSPEKTIF SYARIAH dan ETIKA AAOIFI}

Kata Syara'a berarti mendatangi tempat minum, atau menjadi terbuka atau tampak jelas. Kata Syari'a berarti menghadap terbuka ke arah tertentu. Di dalam Al Qur'an kata Syariat memiliki 2 makna yaitu (1) Aturan,Hukum atau jalan (Asy Syuro 13, Asy Syuro 21, Al Maidah 48, Al Jatsiyah 18). (2) Sesuatu yang terbuka, tampak jelas (Al A'raf 163). Karenanya, ketika mendiskusikan masalah Syariah maka sesungguhnya tidak hanya berorientasi pada aturan, hukum (Fiqih). Dr. M.Yusuf Musa dalam kitab Al Fiqh Al Islami menyebutkan bahwa Syariah (Syariat) mencakup 3 unsur, yaitu:

1. Iktikadi (Ilmu Kalam, Ilmu Tauhid)

2. Akhlaqi (Ilmu Akhlaq, Ilmu Tasawuf, Ilmu Irfan)

3. Fiqih (Hukum Amaliah), yang dibedakan menjadi:

(3.1.) Fiqih Dharuri dan

(3.2.) Fiqih Nazari.

Jika mengacu pada pendapat Dr.M.Yusuf Musa tersebut, maka Moral, dan Etika berkaitan dengan aspek kedua dari syariah, yaitu Akhlaqi. Akhlaqi mencakup unsur-unsur ilmu Akhlaq (moral), tasawuf atau irfan (pendekatan kepada ALLAH SWT melalui proses transenden). Hal tersebut sejalan dengan misi risalah kenabian (Nubuwah) yang dibebankan kepada Nabi Muhammad saww yaitu untuk menyempurnakan Akhlaq manusia (moral manusia); Hendaknya setiap muslim mampu memiliki akhlaq (moral) yang baik sehingga dapat menjadi rahmatan lil alamin (rahmad bagi semesta alam) dan tidak hanya menjadi rahmatan lil muslimin (rahmad bagi kaum muslim yang lain) saja. Dalam konteks muamalah (hubungan sesama manusia), maka kriteria manusia yang memiliki akhlaq baik diwajibkan untuk senantiasa memelihara dirinya agar terhindar dari sifak munafik, yang oleh Nabi saww sifat munafik tersebut diuraikan dalam 3 tanda; (1) Jika berkata bohong, (2) Jika Berjanji sering ingkar, (3) Jika dipercaya, berkhianat.

Selain dari hal-hal tersebut, Syariah juga mengajarkan kepada setiap muslim untuk senantiasa belajar, mengembangkan ilmu pengetahuan dan pemahaman hingga akhir hayat, guna meninggalkan sesuatu yang bermanfaat demi kemaslahatan umat manusia yang hidup pada masa berikutnya; Lisanna sidqin fil akhirin. Belajar tidak hanya untuk memperoleh pengetahuan untuk diri sendiri namun manusia dituntut untuk dapat mengimplementasikan pengetahuan yang didapat dalam aktifitas sehari-hari, sehingga pengetahuan mampu menginternalisasi ke dalam diri manusia menjadi sebuah Ilmu yang bermanfaat 
dalam kehidupan di dunia untuk peradaban manusia dan bekal yang bermanfaat di akherat. Konsistensi untuk senantiasa belajar dan berbuat baik menuju ke kesempurnaan adalah bagian dari ajaran Muhammad saww. Hari ini harus lebih baik dari hari kemarin, dan esok harus lebih baik dari hari ini. Semua hal baik, yang dilakukan muslim didasarkan pada konsep keikhlasan dan semata-mata memohon keridhoan ALLAH SWT bukan untuk pamrih demi mendapatkan pujian atau sanjungan dari sesama (Riya').

Hal lain yang menjadi inti ajaran dalam Akhlaqi adalah konsep Keadilan (adalah). Keadilan merupakan filosofi akhlaq yang menuntut setiap muslim agar dapat berlaku adil bagi diri sendiri dan bagi orang lain. Obyektifitas dalam bertindak, hanya memihak pada kebenaran hakiki sesuai dengan ajaran ALLAH SWT dan RasulNYA merupakan wujud dari implementasi ajaran tentang Keadilan. Keadilan bukan sesuatu yang relatif namun ia adalah sesuatu yang given, sepanjang kita, manusia konsisten mempercayai ALLAH SWT, Nabi SAWW sebagai utusanNYA. Keadilan menjadi sesuatu yang relatif ketika manusia tidak berpegang teguh kepada petunjuk ALLAH SWT dan RasulNYA. Nilai-nilai ini yang kemudian membedakan keadilan menjadi pemahaman keadilan berdasarkan konsep Teologis Illahi dengan pemahaman keadilan berdasarkan konsep sekuler materialistik filosofis.

Apa yang diuraikan secara umum di atas apabila ditarik menjadi sebuah konsep dalam bahasa kekinian, maka akan terdapat beberapa nilai dasar etika moral berdasarkan Syariah, yaitu:

1. Integritas (Kejujuran)

2. Obyektifitas (Obyektif tidak memihak)

3. Kompetensi Profesional (Pengetahuan dan pemahaman profesional)

4. Sincerity (Keikhlasan)

5. Piety (Kesalehan untuk hanya mengharap Ridho dari ALLAH SWT)

6. Keadilan

AAOIFI (Accounting and Auditing Organization for Islamic Financial Institution) yang berkedudukan di Bahrain, yang merupakan organisasi Akuntan yang berpraktek di dunia Bisnis Syariah, merumuskan Etika Profesi Akuntan Publik yang berpraktek di institusi syariah dalam 6 prinsip etika profesi akuntan, yaitu:

1. Trustworthiness, yaitu akuntan harus dapat dipercaya dan jujur dalam menjalankan profesinya.

2. Legitimacy, yaitu akuntan harus memastikan keabsahan segala hal yang berkaitan dengan pelaksanaan profesinya sesuai aturan dan prinsip-prinsip syariah.

3. Objectivity, artinya akuntan harus adil, tidak memihak, bebas dari konflik kepentingan, dan independen dalam fakta dan penampilan.

4. Professional Competence and dilligent, artinya akuntan harus kompeten dan terlatih dengan baik dalam menjalankan tugasnya.

5. Faith driven conduct, artinya perilaku akuntan harus konsisten dengan nilai-nilai agama. 
6. Professional conduct and technical standards, artinya dalam menjalankan tugasnya akuntan harus mematuhi standar akuntansi dan auditing yang ditetapkan AAOIFI.

Secara umum, 6 prinsip etika yang dibangun oleh AAOIFI tersebut, secara substansial mengacu pada prinsip syariah sebagaimana yang diuraikan di atas. Meskipun dalam beberapa hal yang menyangkut ajaran filosofi syariah terutama berkaitan dengan aspek Fiqih, terdapat beberapa hal yang berbeda perspektif, ketika tinjauannya diorientasikan pada ajaran mahzab-mahzab. Format Prinsipprinsip Etika Profesi Akuntan dari AAOIFI, terdiri dari 3 bagian yaitu:

1. Dasar Syariah

2. Prinsip-Prinsip Etika Akuntan, (yang diturunkan dari Dasar-dasar Syariah Islam)

3. Aturan Etika Akuntan, (yang berisi prosedur dan aturan pelaksanaan kode etik yang diturunkan dari prinsip-prinsip umum dalam Prinsip-prinsip Etika Akuntan).

\section{ETIKA PROFESI AKUNTAN AICPA}

Di kalangan negara-negara barat (USA khususnya) orientasi pelaksanaan etika profesi lebih ditujukan pada maksud dan tujuan untuk dapat senantiasa mendapatkan kepercayaan publik dan stakeholder, demi menjaga reputasi dan kredibilitas profesi di tengah-tengah masyarakat. Karenanya landasan Etika Profesi Akuntan yang dibangun oleh AICPA mengemban prinsip nilai-nilai yang diorentasikan guna menjaga reputasi dan kredibilitas tersebut. Beberapa prinsip dasar etika profesi akuntan yang dirumuskan oleh AICPA adalah:

1. Responsibilities, yaitu menjalankan tanggungjawab sebagai seorang profesional

2. The Public Interest, yaitu berorientasi pada pelayanan untuk kepentingan umum, dengan menghargai kepecayaan yang diberikan oleh masyarakat.

3. Integrity, yaitu menjaga kejujuran dalam menjalankan aktifitas profesional.

4. Objectivity and Independent, yaitu menjaga obyektifitas, tidak berpihak, senantiasa bersikap independen dalam menjalankan aktifitas profesionalnya.

5. Due Care, yaitu memahami standar-standar teknis dengan senantiasa secara terus menerus memperbaiki kompetensi dan kualitas pelayanan.

6. Scope and Nature of Services, yaitu memahami prinsip-prinsip kode etik profesi dalam menentukan ruang lingkup dan sifat pelayanan yang diberikan kepada masyarakat.

Jika diteliti secara tajam, maka prinsip-prinsip Etika Profesi Akuntan AICPA banyak dipengaruhi oleh nilai-nilai materialistik dan sekuler serta Permisive yang berkembang di negara-negara barat. Nilai-nilai tersebut mempengaruhi sikap dan tindak masyarakat sehingga menjadi sebuah ajaran ethics yang diakui masyarakat. Ukuran kebenaran biasanya diukur dengan adanya dukungan masyarakat secara luas. Karenanya sebuah nilai dianggap baik apabila mayoritas masyarakat setuju dengan hal tersebut, dan sebaliknya dipandang buruk 
apabila hal tersebut tidak didukung oleh pendapat mayoritas masyarakat. Hal tersebut sejalan dengan terminologi Etika Boynton \& Kell serta Arens-Loebbecke (1996). Dalam referensi AICPA, implementasi pelaksanaan Etika Profesi lebih ditujukan untuk menjamin anggotanya senantiasa mentaati aturan, standar dan hukum yang berlaku, yang mengikat anggotanya. Dengan demikian model Etika Profesi Akuntan AICPA, jika dicoba ditelaah berdasarkan pada 4 gaya pemikiran dari Perkembangan Moral, yaitu Deontological, Teleological, Conventional, Egois (Fraedrich \& Ferrell 1992a, 1992b; Harris \& Sutton,1995; Reidenbach \& Robin,1990), maka prinsip Etika Profesi AICPA, masih berada pada tahapan Conventional, yaitu prinsip etika yang mengacu pada tindakan yang harus bersesuaian dengan Hukum, Norma dan Kode Etik Profesional. Sebuah tingkatan setingkat di atas tahap Egois.

Dengan demikian apa yang terdapat di dalam Kode Etika atau Etika Profesi Akuntan AICPA sebagai sebuah teori dan konsep masih dapat dikatakan belum sepenuhnya idealis untuk sampai pada tahapan pemikiran Teori Etika yang paripurna. Berdasarkan referensi perkembangan pemikiran Moral, tahapan Teleological harus dilalui, untuk sampai pada tahap akhir hirarki pemikiran moral yaitu Deontological.

\section{ETIKA PROFESI AKUNTAN PUBLIK INDONESIA di ERA KOMPETITIF}

Akuntan Publik di Indonesia bergabung di dalam wadah organisasi IAPI (Institut Akuntan Publik Indonesia). IAPI merupakan organisasi baru hasil penjelmaan dari IAI (Ikatan Akuntan Indonesia) Kompartemen Akuntan Publik. Dalam pelaksanaan Etika Profesi, IAPI telah menerbitkan Kode Etik Profesi Akuntan Publik yang dipakai sebagai dasar etika dalam memberikan jasa dan pelayanan Kantor Akuntan Publik, pada bulan Oktober 2008, dan berlaku efektif per 1 Januari 2010. Kode etik ini menggantikan aturan etika yang berlaku sebelum diterbitkannya Kode Etik. Dalam Kode Etik tersebut ditetapkan prinsip dasar dan aturan etika profesi yang harus diterapkan oleh setiap individu dalam KAP, atau jaringan KAP, baik yang merupakan anggota IAPI maupun yang bukan merupakan anggota IAPI, yang memberikan jasa profesional kepada pengguna jasa (baik jasa assurance maupun jasa selain assurance).

Penyusunan ETIKA PROFESI AKUNTAN PUBLIK oleh IAPI ini didasarkan pada perkembangan yang terjadi pada tatanan global dunia usaha, yang ditandai dengan meningkatnya transaksi korporasi lintas batas negara, tuntutan adanya transparansi dan akuntabilitas atas penyajian laporan keuangan. Dengan fakta ini maka IAPI memandang perlu untuk segera "Menyesuaikan diri" dengan standar yang berlaku di dunia International atau Global. Harapannya, Profesi Akuntan Publik di Indonesia dapat meningkat kompetensinya, kualitas, serta daya saingnya, dengan standar profesi dan kode etik yang diakui dan diterima di dunia International.

Di dalam Kode Etik Profesi Akuntan Publik - IAPI, terdiri dari 2 bagian: (Bagian A) berisi prinsip dasar etika profesi yang memberikan kerangka konseptual untuk penerapan prinsip tersebut. (Bagian B) berisi penerapan kerangka konseptual tersebut pada situasi tertentu. Dengan kata lain, Bagian A: berisi Dasar 
Konseptual Etika, Bagian B: berisi Petunjuk Teknis Pelaksanaan Etika Profesi. Prinsip Dasar Etika Profesi Akuntan Publik, yang terdapat di bagian A, terdiri dari:

1. Prinsip Integritas, yaitu setiap praktisi harus tegas dan jujur dalam menjalankan hubungan profesional.

2. Prinsip Obyektifitas, yaitu setiap praktisi harus obyektif, tidak memihak dan tidak boleh membiarkan unsur subyektifitas, benturan kepentingan, mempengaruhi pertimbangan profesionalnya.

3. Prinsip Kompetensi serta Sikap Kecermatan \& Kehati-hatian Profesional (Professional Competence and Due Care), yaitu setiap praktisi wajib memelihara pengetahuan dan keahlian profesionalnya agar senantiasa kompeten dalam melaksanakan aktifitas profesinya sesuai standar profesi dan kode etik profesinya.

4. Prinsip Kerahasiaan, yaitu setiap praktisi wajib menjaga kerahasiaan informasi yang diperolehnya tanpa persetujuan kliennya, sesuai ketentuan perundangan yang berlaku.

5. Prinsip Perilaku Profesional, yaitu setiap praktisi wajib untuk mentaati peraturan dan perundangan yang berlaku.

Dari uraian singkat tersebut di atas, jika kita mencoba untuk mematrikkan Etika Profesi Akuntan dari masing-masing organisasi profesi, yaitu AAOIFI, AICPA dan IAPI, berdasarkan 7 prinsip dasar Etika, K.Bertens, maka akan di dapat matrik sbb:

\begin{tabular}{|c|c|c|c|}
\hline Point of View & AAOIFI & AICPA & IAPI \\
\hline 1. Aspek Kejujuran & Trustworthiness & Integrity & Integritas \\
\hline 2. Aspek Obyektifitas & Objectivity & $\begin{array}{l}\text { Objectivity and } \\
\text { Independent }\end{array}$ & Obyektifitas \\
\hline 3. Aspek Kompetensi & $\begin{array}{l}\text { Professional } \\
\text { Competence and } \\
\text { Dilligent }\end{array}$ & Due Care & $\begin{array}{c}\text { Professional } \\
\text { Competence and } \\
\text { Due Care }\end{array}$ \\
\hline $\begin{array}{l}\text { 4. Aspek Kepatuhan pada } \\
\text { Aturan, Standar, Hukum }\end{array}$ & $\begin{array}{l}\text { - Legitimacy } \\
\text { - Professional } \\
\text { conduct and } \\
\text { Technical } \\
\text { standards }\end{array}$ & Due Care & $\begin{array}{c}\text { Perilaku } \\
\text { Profesional }\end{array}$ \\
\hline $\begin{array}{l}\text { 5. Aspek Kepatuhan pada } \\
\text { Nilai2 moral Agama dan } \\
\text { Keadilan }\end{array}$ & $\begin{array}{l}\text { - Faith-driven } \\
\text { Conduct }\end{array}$ & - & - \\
\hline $\begin{array}{l}\text { 6. Aspek Amanah \& Dapat } \\
\text { Dipercaya }\end{array}$ & Trustworthiness & Public Interest & $\begin{array}{c}\text { Prinsip } \\
\text { Kerahasiaan }\end{array}$ \\
\hline $\begin{array}{l}\text { 7. Aspek Kepatuhan pada } \\
\text { Aturan norma moral } \\
\text { masyarakat }\end{array}$ & $\begin{array}{l}\text { Faith-driven } \\
\text { Conduct }\end{array}$ & Responsibilities & - \\
\hline
\end{tabular}


Gambar 2: Matrik komparasi Etika Profesi berdasarkan 7 aspek Nilai Etika (Data Olahan)

Dari matrik tersebut terlihat beberapa aspek dalam konsep bangun Teori Etika Profesi, berdasarkan pada 7 aspek prinnsip dasar etika, maka produk Etika Profesi AICPA tidak memenuhi 1 aspek yaitu Kepatuhan pada nilai-nilai Agama dan Keadilan, sementara produk Etika Profesi IAPI tidak memenuhi 2 aspek, yaitu Kepatuhan pada nilai-nilai moral Agama dan keadilan serta aspek kepatuhan pada aturan norma moral yang berlaku di masyarakat. Kemudian seperti halnya pada prinsip etika profesi AICPA, maka pada prinsip etika profesi akuntan publik IAPI, berdasarkan pada 4 gaya pemikiran dari Perkembangan Moral, yaitu Deontological, Teleological, Conventional, Egois (Fraedrich \& Ferrell 1992a, 1992b; Harris \& Sutton,1995; Reidenbach \& Robin,1990), maka prinsip Etika Profesi IAPI, juga masih berada pada tahapan Conventional.

Tidak dipungkiri bahwa Indonesia merupakan bagian dari masyarakat dunia. Profesi Akuntan Publik merupakan profesi yang sangat berkaitan dengan profesi yang sama di belahan dunia yang lain, terutama ketika sebuah korporasi melaksanakan aktifitas kegiatan usaha melintas batas wilayah negara dan teritori. Namun, dalam membangun sebuah conceptual framework tentang masalah Etika, semestinya juga harus bersumber pada nilai-nilai etik bangsa bukan sekedar copy, paste dari negara lain. Mengingat nilai-nilai dan semangat yang diusung berbeda, antara Indonesia dengan negara-negara barat. Eksistensi dari Akuntan Publik Indonesia, semestinya tercermin di dalam prinsip dasar etika profesinya, yang kemudian mewarnai aktifitas profesional para akuntan publik dan Kantor Akuntan Publik. Hal ini penting, apabila organisasi memiliki komitmen untuk melakukan pemberdayaan dan pembinaan kepada para akuntan lokal berdasarkan nilai-nilai luhur yang dimiliki bangsa Indonesia. Karenanya, nilai-nilai luhur dari dasar negara; Pancasila, semestinya mewarnai prinsip dasar Etika Profesi Akuntan Publik Indonesia. Hal Ini yang kemudian akan membedakannya dengan Akuntan Publik dan Kantor akuntan Publik dari negara-negara lain di dunia.

Hingga saat ini, kemandirian Akuntan Publik Indonesia masih jauh panggang dari api. Akuntan Publik masih setia sebagai 'agent dari pihak asing' dalam rangka 'mensosialisasikan program-program asingnya' di bidang akuntansi dan keuangan di Indonesia. Hampir semua standar yang berlaku hingga Etika Profesinya, adalah merupakan produk dari asing yang di addopt utuh atau dengan modifikasi sebagian, dan kemudian dijadikan sebagai standar yang berlaku umum di Indonesia. Tidak terlalu salah, namun untuk hal-hal yang bersifat prinsip seperti aturan Etika Profesi semestinya bukan sekedar copy, paste, namun juga seharusnya diupayakan untuk memasukkan nilai-nilai moral etika bangsa dan masyarakat Indonesia, yang karenanya dapat bersumber pada Pancasila sebagai dasar negara.

Di sisi yang lain, aturan tentang perpajakan, undang-undang tentang Investasi, serta pranata hukum Indonesia semestinya juga mencerminkan kepentingan bangsa dan negara demi untuk sebesar-besar kemakmuran rakyat, bukan sekedar ada dan merupakan 'pesanan' komprador asing. Akuntan publik tidak dapat berdiri sendiri, namun terkait dengan hal-hal tersebut saat mereka menjalankan profesi assurance-nya. 
Iran dan Venezuela adalah merupakan contoh dari sebuah negara yang memiliki kemandirian dari segala hal termasuk profesi akuntan publiknya. Mereka tidak alergi terhadap perubahan, mereka bahkan telah melakukan addoption standar laporan keuangan IFRS, IAS serta ISA, namun menyangkut etika Profesi akuntan publik, negara tersebut memiliki konsep yang sedikit berbeda dalam membangun conceptual framework. Nilai-nilai moral yang mereka anut, masuk di dalam prinsip etika profesi akuntan. Akibatnya, pada saat sebuah KAP disana melakukan audit yang berkaitan dengan sumber daya alam yang dimiliki negara, mereka ekstra hatihati, untuk menjaga jangan sampai terdapat hal-hal yang merugikan negara dan rakyatnya, tidak diketahui oleh auditor, meski KAP tersebut merupakan member dari Big Four, namun kemandirian akuntan lokal tetap terlihat. Demikian juga halnya dengan China yang merupakan negara Komunis. Semangat nasionalisme Akuntan Publiknya sangat tinggi.

Hal-hal seperti inilah yang patut dibangun sebagai dasar etika profesi akuntan publik di Indonesia dalam era globalisasi dan kompetitif saat ini. Tanpa hal tersebut maka akuntan publik Indonesia tidak akan memiliki identitas, kemandirian serta posisi bargain. Globalisasi bukan berarti harus meninggalkan kepentingan bangsa dan negara, Globalisasi tidak boleh diartikan sebagai penyeragaman kepentingan yang disesuaikan dengan kepentingan asing, namun harus tetap menjunjung tinggi prinsip-prinsip nasionalisme Indonesia. Dalam hal ini selain organisasi IAPI yang memiliki tugas dan fungsi untuk melindungi dan memberdayakan akuntan publik lokal, maka Pemerintah beserta DPR melalui perangkat aturan yang dikeluarkannya juga turut melindungi keberadaan dari akuntan publik lokal, dan tidak gampang-gampang membuat aturan yang memungkinkan pihak asing untuk bebas berprofesi di wilayah negara Indonesia. Faktanya saat ini, aturan membolehkan asing berpraktek sebagai akuntan publik di Indonesia. Sangat berbeda dengan profesi Dokter dan Lawyer, yang begitu melindungi kepentingan profesinya. Dengan kondisi yang seperti ini maka fungsi Pemerintah dan organisasi IAPI yang dimaksudkan untuk menjaga dan melindungi profesi akuntan publik dalam rangka pembinaan akan menjadi tidak tercapai. Dan bukan tidak mungkin justru yang terjadi adalah sebaliknya: pembinasaan profesi akuntan publik.

Sebagai sebuah gambaran ketidakberdayaan akuntan publik Indonesia saat ini, adalah tampak dalam rencana penghapusan standar akuntansi perkoperasian (PSAK 27) karena dipandang tidak sejalan, tidak comparable dengan standar International IFRS dan IAS. Tentu saja! karena Koperasi adalah aktifitas usaha yang hanya ada di Indonesia. Dan Koperasi dalam UUD 45 disebutkan sebagai soko guru perekonomian bangsa, karenanya bersifat unik, tipikal Indonesia. Melihat hal tersebut, semestinya para ahli di bidang akuntansi berupaya untuk lebih mengembangkan standar akuntansi perkoperasian tersebut agar memiliki kualitas pelaporan yang lebih transparan dan akuntabel, dan bukan justru akan menghapuskannya dan menggantikannya dengan standar ETAP (Entitas Tanpa Akuntabilitas Publik) yang di adopsi dari SME (Small and Medium Enterprises) IFRS, yang karenanya standar ETAP disebut sebagai "Mini IFRS".

Dari uraian tersebut, maka dalam era globalisasi di masa kompetitif saat ini, tidak sepatutnya Pemerintah dan DPR melepas kran persaingan bebas untuk profesi akuntan publik demi mendapatkan predikat sebagai negara yang demokratis 
dan konsisten dengan prinsip AFTA dan NAFTA. Kesalahan di dalam membuat kebijakan akan berakibat fatal bagi perkembangan profesi akuntan publik di masa depan. Dan bukan tidak mungkin, nantinya akuntan publik asing akan datang 'menyerbu' Indonesia dan berpraktek di Indonesia secara leluasa. Dalam kondisi yang seperti ini, maka lulusan akuntansi dari fakultas ekonomi akan kehilangan kesempatan untuk berprofesi sebagai akuntan publik, serta profesi akuntan yang lain. Gejala seperti ini sudah mulai tampak saat ini, di kota-kota besar di Indonesia, seperti Jakarta dan Surabaya. Saat ini banyak dari perusahaan-perusahaan multinasional mulai mencari akuntan lulusan dari Singapura, Malaysia, Filipina, India, China, ketimbang lulusan lokal Indonesia. Sementara untuk profesi akuntan publik, entitas PMA maupun yang listed di BEI, senantiasa mencari auditor yang berasal dari KAP asing atau setidaknya yang telah berafiliasi dengan asing.

Di sisi yang lain, perguruan tinggi harus dapat berperan dengan lebih aktif dengan melakukan pendidikan akuntansi secara profesional dan memadai, agar lulusannya dapat lebih kompeten dan memiliki dasar-dasar etika profesi sebagai seorang akuntan. Hal ini sejalan dengan pendapat Sudibyo (1995) dalam Khomsiyah dan Indriantoro (1998): bahwa Dunia Pendidikan Akuntansi memiliki pengaruh yang besar terhadap perilaku Etika dari Auditor khususnya.

\section{DAFTAR PUSTAKA}

Allen, P.W. and C.K. (2001), "Self interest among CPAs may influence their moral reasoning", Journal of Business Ethics, Vol. 33 No. 1, pp.29-35

Alleyne, P., Devonish D., Nurse, J. (2006), "Perception of Moral Intensity Among Undergraduate Accounting Students in Barbados", Journal of Eastern Carribean Studies, Vol.31, pp. 1-26.

Aranya, N., dan K.R. Ferris. 1984. Reexamination of Accountants' OrganizationalProfessional Confic. The Accounting Review.

Aranya, N., J. Pollock, dan J. Amernic. 1981. An Examination of Professional Commitmen in Public Accounting. Accounting, Organization and Society. Vol. 6. Pp. 271-280.

Arens\&Loebbecke. 1998. “Auditing: Integrated Appro-ach”. Prentice Hall. pp. 68.

Arifin Sabeni. 2005. "Peran Akuntan Dalam Menegakkan Prinsip Good Coorporate Governanca (Tinjauan Perspektif Agency Theory)". Badan Penerbit Universitas Diponegoro, Semarang.

Arnold, D. And Ponemon, L. 1991. "Internal auditors perceptions of whistleblowing and the influence of moral reasoning: an experiment", Auditing: A Journal of Practice \& Theory, Fall, pp. 1-15. 
Bebeau, M. J., J. R. Rest, dan C. M. Yamoor. 1985. Measuring Dental Students Ethical Sensitivity. Journal of Dental Education. Vol. 49. Pp. 225-235.

Bertens K., 2000. “Etika”, Gramedia Pustaka Utama. Jakarta. pp. 4-7.

Buchan, H.F. 2005. Ethical Decision Making in the Public Accounting profession: an extension of Ajzen's theory of Planned behaviour", Journal of Business Ethics, Vol.61 No.2, pp. 165-181.

Budi Sasongko, dkk. 2007. Internal Auditor dan Dilema Etika. www.theaccounting.com

Chua, F.C M.H.B. Perera and M.R Mathews. 1994. Integration of Ethics Into Tertiary Accounting Programes in New Zealand and Australia.

Cohen, J.R. and Bennie, N.M. 2006. "The Applicability of Contingent Factors Model to Accounting Ethics Research", Journal of Businees Ethics, Vol. 68, pp. 1-18.

Douglas, P.C., R. A. Davidson and B.N. Schwartz. 2001. "The Effect of Organizational Culture and Ethical Orientation on Accountants Ethical Judgements", Journal of Business Ethics, Vol. 34(2), h. 101-121.

Echols, J.M. dan Shadily, H. 1995. Kamus Inggris Indonesia. Jakarta: Gramedia Pustaka Utama.

Ellias, R.Z. 2002. "Determinants of Earnings Management Ethics Among Accountants", Journal of Business Ethics Vol. 40 No.1, pp. 33-45.

Falah, S. 2006. Pengaruh Budaya Etis Organisasi dan Orietasi Etis terhadap Sensitivitas Etis, Tesis Magister Sains Akuntansi, Universitas Diponegoro, Semarang.

Fiin, D.W., L.B Chonko, and J.D Hunt. 1988. "Ethical Problem in Public Accounting: The View from The Top", Journal of Business Ethics Vol.7 pp. 605-615.

Fischer, marilyn, and K. Rosenzweig. 1995. Attitudes of Students and Accounting Practitioners Concerning the Ethical Acceptability of Earnings Managements, Journal of Businees Ethics 14:443-444.

Forsyth,D.R 1980. “A taxonomiof ethical ideologies".Journal of personality and sosial psychology 39:175-184

Fraedrich, J.P.,\& Ferrel,O.C (1992a),Cognitive consistency of marketing managers in ethical situations, Jounal of Academy of Marketing Scirence, 20,245252. 
Frey,B.F. 2000. "The impac of moral intensity on decision making in business context". Journal of Business Ethics.No26:181-195

Hoesada,jan.1996."Etika Bisnis dan profesi di era Globalisasi”.Media Akuntansi.No.21

Hal 5-7

Hunt, S.D and Vitell. 1986. "A General Theory of Marketing Ethics". Journal of Macromarketing 6 (Spring) pp. 5-16.

Jeffrey, C. And Weatherholt, N. 1996. "Ethical decision making by individuals in organizations" : An issue-contingent model. Academy Management Review 16(2):pp.336-395.

Karcher, J.N. 1996. "Auditors ability to discern the presence of ethical problems", Journal of Business Ethics Vol. 15 No. 10, pp. 1033-50.

Keraf, Sonny. 1998. "Kemerosotan Moral Profesi Akuntansi”. Seminar Nasional Strategi Pendidikan Etika \& Etika Profesi Akuntansi di Indonesia. FEEUsakti, Jakarta.

Khomsiyah dan Nur Indriantoro. 1998. "Pengaruh Orientasi Etika terhadap Komitmen dan Sensitivitas Etika Auditor Pemerintah di DKI Jakarta". Jurnal Riset Akuntansi Indonesia Vol.1 Januari hal. 13-28.

Leitsch, Deborah L., 2004. "Differences in the Perceptions of Moral Intensity in the Moral Decision Process: An Empirical Examination of Accounting Students”. Journal of Business Ethics 53: 313-323, 2004.

Volker, J.M., 1984. Couseling Experience, Moral Judgement, Awareness of Consequences, and Moral Sensitivity in Counseling Practice. Unpublished Doctoral Disertation. Minneapolis, MN: University of Minnesota Press.

Widiastuti, Indah. 2004. Pengaruh Perbedaan Level Hirerarkis Akuntan Publik dalam Kantor Akuntan Publik terhadap Persepsi tentang Kode Etik Akuntan Indonesia. Jurnal Akuntansi\&Bisnis Vol.3(1) Feb: 53-65.

AAOIFI, 1998, Accounting and Auditing Standars for Islamic Financial Institution, State of Bahrain.

Abdullah Amalina. 2002. Predicting Unethical Behavior in Accounting And Financial Reporting: Applying The Theory of Planned Behaviour. Jounal Business Ethics.

Brooks, Leonard L., 1999. Business and Professional Ethics for Accountants $2^{\text {nd }}$ Edition, South Western College Publishing. 
Copeland, Jr. James, 2005. Ethics as an Imperative, Accounting Horizon, pp. 3543.

Fisher Collin and Lovell Allan. 2003. Business Ethics and Values. Prentice Hall.

Satyanugraha, Heru. 2003. Etika Bisnis: Prinsip dan Aplikasi, Lembaga Penerbit Fakultas Ekonomi Universitas Trisakti, Jakarta.

Weiss Joseph W. 2003. Bussiness Ethics A Stakeholders and Issue Management Approach, Third Edition, Thomson South Western.

Windsor, C. 1995. Moral reaaoning developmentand believe in a just world as a precursors of auditor independence: the role of organizational culture perceptions". Proceedings of the Second Annual ABO Research Conference.

Yulianty dan Fitryani. 2005. Persepsi Mahasiswa Akuntansi Terhadap Etika Penyusunan Laporan Keuangan. Simposium Nasional Akuntansi VIII. 1516 September 2005.

Ziegenfuss, D. E. And A. Singhapakdi. 1994. Professional Values and Ethical Perceptions of Internal auditors". Managerial Auditing Journal Vol. 9 No. 1.

Febianty. 2011. Perkembangan Model Moral Kognitif Dan Relevansinya dalam Riset-Riset Akuntansi, Jurnal Ekonomi dan Informasi Akuntansi (JENIUS). Palembang: Universitas Tridinanti.

Reni, Dewi SE.Ak.,M.Si. 2006. Etika Profesi akuntan Dalam Pandangan Islam. 